\title{
FILOSOFIA NO SEGUNDO GRAU: \\ NECESSIDADE E UTILIDADE \\ DOS TEXTOS CLÁSSICOS*
}

\section{RICARDO MONTEAGUDO}

Mestrando em Filosofia

FFLCH-USP

$$
\begin{aligned}
& \text { "O ensino de filosofia vale o que vale o } \\
& \text { professor de filosofia." } \\
& \text { Jean Maugüé }
\end{aligned}
$$

O território da filosofia enquanto disciplina do $2^{\circ}$ Grau deve compreender o vínculo entre os textos já consagrados pela tradição filosófica e a vivência pessoal do aluno. No primeiro nó reside o esforço necessário, no segundo, a utilidade e o interesse.

Partindo do princípio de que o estabelecimento de um parâmetro bem definido para a reflexão é útil para a formação do aluno e indispensável para sua posterior autonomia, pretendo salientar que, para a filosofia no segundo grau, o melhor parâmetro bem definido provém do universo clássico da história da filosofia.

A principal dificuldade não creio que seja a seleção do texto a ser trabalhado, já que o universo filosófico clássico é suficientemente amplo, mas o caminho para chegar nesse texto'. Se o adolescente não reconhecer alguma afinidade do tema com sua vivência cotidiana, este se tornará puramente abstrato ou metafísico, isto é, vazio de significado e pronto para ser esquecido no dia seguinte. Com isso, é muitas vezes necessário fazer concessões ao rigor para tornar o texto inteligível para o "mundo" do aluno, deixando de lado as exigências teóricas da academia.

Essas concessões são estrategicamente retóricas e visam a compreensão do texto. Vale dizer, todos os recursos de comunicação são válidos para acordar o significado do texto. Aos poucos, lendo e escrevendo, o aluno aprende a distinguir consistência lógica e logro

Este trabalho foi apresentado no VII Encontro Nacional de Filosofia da ANPOF (Associação Nacional de Pós-Graduação) de 1996, em Águas de Lindóia.

${ }^{1}$ Cf. Celso Favaretto, "Notas sobre o Ensino de Filosofia" in: Filosofia e seu Ensino; Ed. Vozes/Educ, Petrópolis/São Paulo, 1995; p. 78. 
retórico ${ }^{2}$, pois essa distinção caracteriza o próprio objeto da filosofia. Para que a mistificação ilustrada do primeiro momento se supere tornando-se esclarecimento, a reflexão do aluno por meio da escrita é indispensável: as regras de gramática contidas no texto impedem desvios semânticos e tornam a retórica refém do argumento, da lógica textual.

O professor auxilia com a contextualização e com a interpretação, o aluno participa com o esforço de atualização de um texto aparentemente extemporâneo mas que ajudou a compor o presente. Algumas alusões feitas pelos alunos são surpreendentes e o próprio professor reconhecerá relações inusitadas que enriquecem a interpretação do texto. Aos poucos, o aluno saberá discriminar as relações corretas das relações fantasiosas.

Note que aparentemente a posição do professor é autoritária, pois é o professor que explica o texto e dá a palavra final sobre seu significado, no entanto, a função arcôntica ${ }^{3}$ do professor só adquire sentido pedagógico se $o$ aluno mantiver a função contrária, anarcôntica, quebrando a lógica interna inicial para reconstrui-la em seguida. A atenção do professor a essa função anarcôntica do aluno é o que atualizará o texto clássico já estabelecido pela tradição, ou seja, que tornará o texto clássico ativo para o cotidiano contemporâneo. Isso converte o professor de filosofia do segundo grau no único verdadeiro "filósofo", pois sua profissão o obriga a permanecer atento à atualidade dos conteúdos reflexivos do passado na sua forma ingênua contemporânea. A luta pela descoberta ou pela reprodução ou pela explicitação da realidade no texto é assim o melhor procedimento para a emergência da autonomia ou da maioridade intelectual.

O grande avanço é eliminar o fantasma do texto clássico e mostrar que para bem compreendê-lo basta vontade, persistência e um pouco de treino (ou hábito), ainda que a primeira leitura seja equivocada. Se, findo o segundo grau, o jovem se sentir seguro para tentar fazer uma interpretação séria e consistente de qualquer texto por escrito, teremos sido bem sucedidos, pois ele será capaz de formalizar

${ }^{2}$ Cf. indicado por Ricardo Fabbrini, "O Ensino de Filosofia no $2^{\circ}$ grau: Uma língua da Segurança". in: Filosofia e seu Ensino; Ed. Vozes/Educ, Petrópolis/São Paulo, 1995; p. 89. ${ }^{3}$ Cf. Bento Prado Jr, "Por que Filósofo? - Os Limites da Aufklärung" in: Estudos Cebrap, no 15, São Paulo, jan-fev-mar 1976, pp. 170 e ss. 
os problemas que o mundo lhe apresenta e estará sempre disposto a enfrentá-los.

Essa orientação pedagógica aumenta a relevância da interdisciplinaridade e confere uma grande responsabilidade à filosofia. Praticamente todas as disciplinas estão preocupadas com o rompimento dos lugares-comuns vulgarizados pela mídia, sobretudo pela televisão. Um dos caminhos de trabalho com filosofia é o estranhamento, romper o lacre das ilusões e mostrar semelhanças onde aparecem diferenças e diferenças onde aparecem semelhanças. Essa trajetória delimita a liberdade e a autonomia de cada um em relação às suas responsabilidades, ainda que seja apenas uma "impressão de consciência", trata-se em filosofia de discutir a prática de cada um e sua justificação - e isso de maneira flagrante no segundo grau. No entanto, essa função não é tarefa exclusiva da filosofia.

Costuma-se dizer que a filosofia promove a reflexão crítica, a articulação conceitual e a tomada de consciência sobre o mundo, como se as outras disciplinas não tivessem essa mesma preocupação e como se se tratasse de uma poção mágica pela qual sem qualquer esforço adquiríssemos maioridade intelectual. Não podemos eliminar as peculiaridades da filosofia que são o que a caracterizam como campo de pesquisa próprio e o que a capacitam a apoiar pesquisas em outras áreas.

Estudar filosofia é estudar filosofias ${ }^{4}$, ou seja, é debruçar-se sobre a história da filosofia, seus problemas e suas soluções, nunca sem antes demonstrar a proximidade que este trabalho tem no cotidiano de cada um. A filosofia se relaciona com sua história de modo a torná-la permanentemente presente, não de maneira cumulativa ou progressiva, como por exemplo acontece com as ciências naturais, mas de maneira direta. Quando estudamos Platão ou Sartre, sabemos que sua filosofia foi produzida em determinadas condições históricas e que só podemos reinterpretar seu pensamento a partir das nossas próprias condições. Filosofar é sempre recomeçar a filosofar. Isso significa que fazemos uma tradução para uma nova conjuntura cultural que produz uma nova reflexão.

${ }^{4}$ Cf. Franklin Leopoldo e Silva, "Introdução ao Estudo da História da Filosofia" in: Fascículo introdutório da Coleção Os Pensadores, Ed. Abril, São Paulo. 
Estamos assim condenados a recriar: cada momento da nossa vida é absolutamente novo e precisamos sempre recorrer a algo velho para explicá-lo. Essa relação obrigatoriamente direta com a tradição filosófica é a forma própria do filosofar. Lembro-me de Kant: "Não se aprende filosofia, quando muito se aprende a filosofar" Precisamente, filosofia se produz com esse diálogo franco e permanente com o passado.

Trata-se então de convidar os alunos a uma viagem de descoberta, uma espécie de turismo pela história do pensamento verificando de que maneira reproduzimos muitas vezes determinadas idéias sem nos darmos conta de que elas exigiram uma longa experiência intelectual antes de chegarem até nós. Não se trata de historicismo ou determinismo, mas, se preferirmos, de recurso pedagógico. O mundo de Platão, por exemplo, está morto para nós, ele não foi cristão, nem viveu em sociedade de mercado e muito menos numa "república" Sua obra, entretanto, sobrevive intensa e pujante. Ou nunca ninguém teve um "amor platônico"?

A filosofia pode por isso ser acusada de necrofilia intelectual: não trabalhamos com atualidades mas com a atualização de conhecimentos vigorosos do passado que ainda muito têm a contribuir.

Como Frankenstein, integramos conhecimentos aparentemente díspares com a finalidade de catalisar a consciência do adolescente sobre o mundo de modo que ele não se deixe levar por retóricas destrutivas cujo substrato social é escamoteado. 